Lieberman, J. (1969). New England fournal of Medicine, 281, 279. Lieberman, J., Mittman, C., and Gordon, H. W. (1972), Science, 175, 63. Makino, S., and Reed, C. E. (1969). Fournal of Laboratory and Clinical Medicine, 74, 987.

Ohlsson, K. (1971a). Scandinavian fournal of Clinical and Laboratory Investigation, 28, 219.

Ohlsson, K. (1971b). Scandinavian fournal of Clinical and Laboratory Investigation, 28, 251.

Pederson, J. T., Weeke, B., and George, J. (1969). Danish Medical Bulletin, $16,283$.
Sharp, H., Krivit, W., and Lowman, J. T. (1967). Fournal of Pediatrics, 70, 46. Sharp, H. L., Bridges, R. A., Krivit, W., and Freier, E. M. (1969). Fournal of Laboratory and Clinical Medicine, 73, 934.

Sharp, H. L. (1971). Hospital Practice, 6, 83.

Shiraki, K., Okamoto, Y., and Takatsu, T. (1966). Paediatria Universitatis Tokyo, 12, 41 .

Shulman, V. R. (1970). American fournal of Medicine, 49, 619. Thaler, M. M., and Gellis, S. S. (1968). American Fournal of Diseases of

Zuckerman, A. J. (1970). Bulletin of the World Health Organization, 42, 957.

\title{
Effect of Electric Convulsion Therapy on Urinary Excretion of 3', 5' Cyclic Adenosine Monophosphate
}

\author{
K. HAMADAH, HELEN HOLMES, \\ G. B. BARKER, \\ G .C. HARTMAN, \\ D. V. W. PARKE
}

British Medical fournal, 1972, 3, 439-441

\section{Summary}

Electric convulsion therapy (E.C.T.) was used in the treatment of 13 women inpatients sufiering from depressive symptoms. Twelve of the patients showed a significant increase in urinary excretion of $3^{\prime}, 5^{\prime}$ cyclic adenosine monophosphate (cAMP) on the day of treatment, whereas four controls who received all or part of the preliminary treatment but no electric shock showed a reduction. The results of this study are consistent with the hypothesis that the antidepressant action of E.C.T. is mediated through an increased production of cAMP in brain tissue.

\section{Introduction}

Abnormally low excretion of $3^{\prime}, 5^{\prime}$ cyclic adenosine monophosphate (cAMP) has been reported in patients with depressive illness (Abdulla and Hamadah, 1970; Paul et al., 1970). Abdulla and Hamadah suggested that depressive illness is due to a severe fall in the intracellular level of cAMP in all tissues, including those of the central nervous system. Several factors have been found to influence cAMP levels in body fluids and tissues. An increase in the urinary level has been noted after the administration of tricyclic antidepressants, and these have been shown to be inhibitors of cAMP phosphodiesterase (Abdulla and Hamadah, 1970; Ramsden, 1970). Recent studies by Kodama et al. (1971) on brain slices suggest that imipramine, desipramine, and amitriptyline stimulate the formation of cAMP. Electrical stimulation has also been found to increase the level of cAMP in cerebral cortical slices (Kakiuchi et al., 1969; Shimizu et al., 1970), and this response was synergistic with that of histamine or noradrenaline but was prevented by previous treatment with a methylxanthine such as theophylline (Kakiuchi et al., 1969; Sattin and Rall, 1970).

Electric convulsion therapy (E.C.T.) has long been accepted as an effective form of treatment in some types of depression, and we therefore decided to examine the effect of E.C.T. on the urinary excretion of CAMP.

Tooting Bec Hospital, London S.W.17

K. HAMADAH, M.B., D.P.M., Psychiatrist

HELEN HOLMES, B.sC., Research Assistant

G. B. BARKER, M.B., D.P.M., Consultant Psychiatrist

University of Surrey, Guildford, Surrey

G. C. HARTMAN, DIP.TECH., Lecturer in Biochemistry

D. V. W. PARKE, PH.D., P.R.I.c., Head of Biochemistry Department

\section{Patients and Methods}

The investigation was carried out on 14 women inpatients at Tooting Bec Hospital suffering from depressive symptoms who were judged clinically to require treatment with E.C.T. The only additional criteria for selection were the willingness and the ability of the patients to co-operate in the investigation. Patients with heart or kidney diseases were excluded. The age range was from 24 to 61 years. Throughout the period of the study the patients were given a diet that lacked foods which might affect indole and catecholamine excretion (Paul et al., 1970). No alcohol was permitted and tea and coffee intake was stabilized. Patients were clinically assessed on the day before E.C.T., on the day of treatment, and on the following day to detect any sudden or pronounced change in mood. All participants received antidepressants or tranquillizers, or both, the doses of which were fixed throughout the period of the study.

E.C.T. was administered regularly between 09.30 and 11.00 hours on Tuesdays and Fridays. All patients received $0.6 \mathrm{mg}$ of atropine sulphate as premedication half to one hour before treatment. In 11 patients, who received a total of 19 treatments, the convulsion was modified by the intravenous injection of $60-70 \mathrm{mg}$ of methohexitone sodium and $25-50 \mathrm{mg}$ of suxamethonium chloride immediately before E.C.T. In the last two patients in the E.C.T. group, who received a total of seven treatments, the convulsion was modified by the intravenous injection of $250 \mathrm{mg}$ of thiopentone sodium and $30-50 \mathrm{mg}$ of suxamethonium bromide. The E.C.T. was administered with an Ectonus mark 3 A.C. mains model (Ectron Ltd.). The electrodes (Ectonus head-band) were lightly soaked in Ectronolyte solution and applied bitemporofrontally. The rotary control was used to apply the potential in a series of increasing steps, reaching a maximum of $140 \mathrm{~V}$; the current was passed for about one second. The patients were well oxygenated with $100 \%$ oxygen.

On three occasions patients received all the preliminary treatment but for various reasons, including instrument failure, no shock was delivered. As they had experienced the anticipatory anxiety and had received atropine sulphate, methohexitone sodium, suxamethonium chloride, but not the electric shock they were regarded as controls on these occasions. A fourth patient, who received the atropine sulphate but panicked before further treatment could be given and refused it, was regarded as a separate control. Thus the controls (see Table) were achieved by chance rather than design. It was felt to be unacceptable on ethical grounds to enlarge this control group.

Twenty-four-hour specimens of urine (07.00-07.00 hours) were collected for up to three days before the first E.C.T. to establish a baseline for each individual patient and to determine the day-to-day variation of cAMP excretion. Twenty-four-hour specimens were also collected on the day of E.C.T., for two days after E.C.T., and, where appropriate, on the days between subsequent treatments. The total urinary output over each 
Effect of E.C.T., on Urinary 3', 5' Cyclic Adenosine Monophosphate

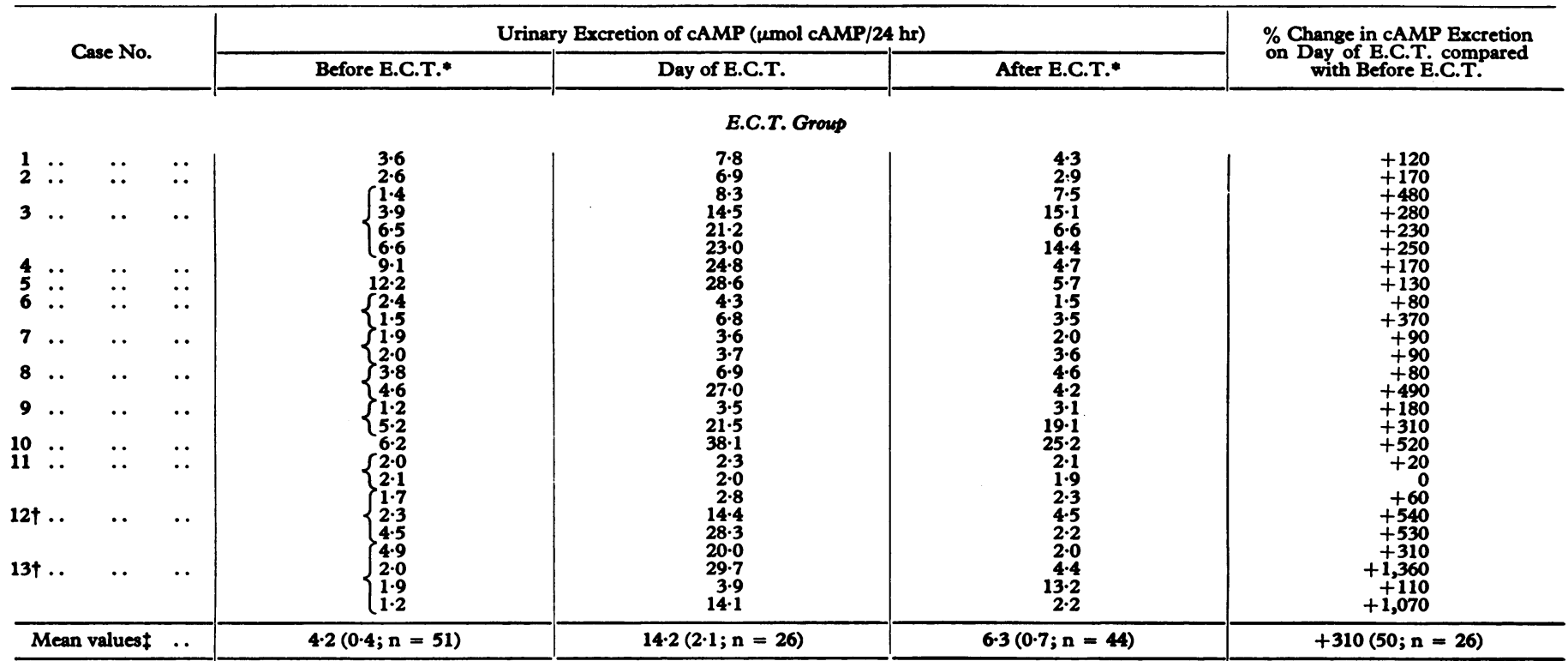

\begin{tabular}{|c|c|c|c|c|c|}
\hline \multirow[b]{2}{*}{$\begin{array}{r}4 \\
5 \\
14 \\
14 \\
108\end{array}$} & \multicolumn{5}{|c|}{ Control Grous (No E.C.T.) } \\
\hline & $\begin{array}{ll}\because & \\
\because & \\
\because & \end{array}$ & $\begin{array}{r}26 \cdot 1 \\
9 \cdot 3 \\
5 \cdot 1 \\
3.0\end{array}$ & $\begin{array}{r}24.6 \\
7.9 \\
3.7 \\
1.0\end{array}$ & $\begin{array}{r}20.3 \\
5.0 \\
0.9 \\
0.9\end{array}$ & $\begin{array}{r}-6 \\
-16 \\
-27 \\
-67\end{array}$ \\
\hline
\end{tabular}

* Mean value (where appropriate).

†Patient received thiopentone sodium instead of methohexitone sodium.

IMean values with S.E. of mean and number of samples in parentheses.

8 Patient received $0.6 \mathrm{mg}$ atropine sulphate only.

Comparison of the paired data for cAMP excretion before E.C.T. with excretion on the day of B.C.T. gives P <0.001. For Cases 9-13 a double-blind procedure was used. Only after assaying all specimens was the code disclosed.

24-hour period was pooled over $1 \mathrm{ml}$ of chloroform, thoroughly mixed, and a $10-\mathrm{ml}$ sample stored at $-20^{\circ} \mathrm{C}$ until analysis. The completeness of the collection was checked by determination of the creatinine content as described by Varley (1969). cAMP was determined by the enzymic-radioisotopic displacement method essentially as described by Brooker et al. (1968).

\section{Results}

The changes in CAMP excretion resulting from the administration of E.C.T. in a typical case are shown in the Chart. Twelve of the 13 patients who received E.C.T. (see Table) showed a significant rise in urinary CAMP excretion on the day of treatment, when the mean value for the 13 patients (26 treatments) was $14.2 \mu \mathrm{mol} / 24 \mathrm{hr}$ compared with a mean of $4.2 \mu \mathrm{mol} / 24 \mathrm{hr}$ for the period before E.C.T. $(P<0.001)$. In general the excretion of cAMP fell on the following day but not necessarily to the pre-E.C.T. level. The four controls showed a fall in the urinary excretion of cAMP on the day of (abortive) treatment (see Table).

\section{Discussion}

A rise in urinary cAMP excretion after E.C.T. could be due to one or more of the following factors: anticipatory anxiety, premedication, anaesthesia, the administration of muscle relaxant, hypoxia, or electrical stimulation. The failure of the four controls to show any increase in cAMP excretion suggests that E.C.T. was the major factor responsible for the rise in cAMP excretion observed in this investigation. This conclusion is supported by the results of other studies. The work of Cox and Potkonjuk (1969), and of Robison et al. (1971) suggests that atropine would have little or no effect at the dose level used. Wilson (1969) showed that barbiturates lower cAMP levels in

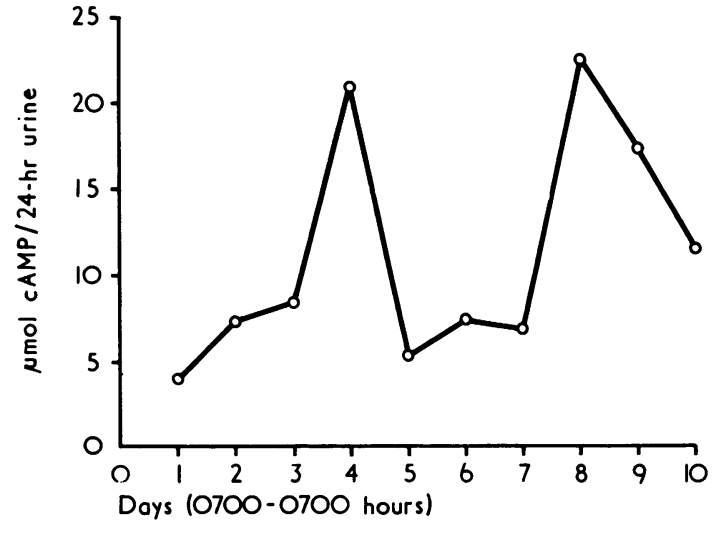

Daily urinary cAMP excretion in a patient who received E.C.T. on days 4 and 8.

the rat brain, and Havens et al. (1959) showed that thiopentone and suxamethonium reduce the postconvulsive levels of catecholamines in the plasma of patients undergoing E.C.T. and hence probably also lower cAMP levels (Robison et al., 1971).

The procedure used in E.C.T. needs to be carefully controlled to prevent hypoxia, which can result in various biochemical changes. Thus Havens et al. (1959) showed that the postconvulsive plasma level of adrenaline bears an inverse relation to the degree of oxygenation of the patient, while anoxia leads to a definite increase in the level of cAMP in mouse and rat brain (Goldberg et al., 1970; Ditzion et al., 1970). In the present study the patients were well oxygenated, and the lack of increase in CAMP level in the three suxamethonium-treated controls again points to convulsive electric shock as the causative factor.

The mechanism by which electrical stimulation increases the 
level of CAMP in the brain remains to be established. Although the direct administration of the monoamines noradrenaline and histamine into rat cerebral cortex causes prolonged activation of adenyl cyclase (Chou et al., 1971) the E.C.T.-induced increase in brain cAMP content cannot be completely explained by the action of these amines, since electrical stimulation of guinea-pig cerebral cortex produces an accumulation of cAMP over and above that produced by either noradrenaline or histamine (Rall and Sattin, 1970). Currently the most plausible suggestion is that depolarization results in increased release of adenine-ribose compounds, which then stimulate cAMP formation (Rall and Sattin, 1970).

This study has shown that E.C.T. produced an increase in the urinary excretion of $\mathrm{CAMP}$, which may be due to increased tissue levels of cAMP or to an increased rate of elimination. The direct electrical stimulation of slices of guinea-pig cerebral cortex, however, rapidly produces a greatly increased level of cortical cAMP (Kakiuchi et al., 1969; Shimizu et al., 1970), and, furthermore, evidence has been obtained to support the suggestion that CAMP mediates the physiological actions of neural transmitter substances in the central nervous system (Florendo et al., 1971; Greengard and Kuo, 1970). Possibly, therefore, the antidepressant action of E.C.T. is mediated through an increased production of cAMP in the brain, which is reflected in the increase observed in the urine of E.C.T.-treated patients.

We thank Mr. Z. Carrasco, Sister E. Carlson, and other members of the staff of Tooting Bec Hospital for their help. We are grateful to the patients involved in this study for their co-operation.
This work was supported by a grant from the South-West Metropolitan Regional Hospital Board.

\section{References}

Abdulla, Y. H, and Hamadah, K. (1970), Lancet, $1,378$.

Brooker, G., Thomas, L. J., and Appleman, M. M. (1968). Biochemistry, 7, 4177 .

Chou, W. S., Ho, A. K. S., and Loh, H. H. (1971). Nature New Biology, 233, 280.

Cox, B., and Potkonjuk, D. (1969). British fournal of Pharmacology, and Chemotherapy, 35, 521 .

Ditzion, B. R., Paul, M. I., and Pauk, G. L. (1970). Pharmacology, 3, 25.

Florendo, N. T., Barrnett, R. J., and Greengard, P. (1971). Science, 173, 745. Goldberg, N. D., Lust, W. D., O'Dea, R. F., Wei, S., and O'Toole, A. G. (1970). In Role of Cyclic AMP in Cell Function, ed. P. Greengard, and E. Costa, p. 67. New York, Raven Press.

Greengard, P., and Kuo, J. F. (1970). In Role of Cyclic AMP in Cell Function, ed. P. Greengard, and E. Costa, p. 287. New York, Raven Press.

Havens, L. L., Zileli, M. S., DiMascio, A., Boling, L., and Goldfien, A. (1959). Fournal of Mental Science, 105, 821.

Kakiuchi, S., Rall, T. W., and McIlwain, H. (1969). Gournal of Neurochemistry, 16, 485 .

Kodama, T., Matsukada, Y., Suzuki, T., Tanaki, S., and Shimizu, H. (1971). Biochimica et Biophysica Acta, 252, 165.

Paul, M. I., Ditzion, B. R., Pauk, G. L., and Janowsky, D. S. (1970). American fournal of Psychiatry, 126, 1493.

Rall, T. W., and Sattin, A. (1970). In Role of Cyclic AMP in Cell Function, ed. P. Greengard, and E. Costa, p. 113. New York, Raven Press.

Ramsden, E. N. (1970). Biochemical fournal, 120, 12P.

Sattin, A., and Rall, T. W. (1970). Molecular Pharmacology, 6, 13.

Robison, G. A., Butcher, R. W., and Sutherland, E. W. (1971). In Cyclic $A M P$. New York, Academic Press.

Shimizu, H., Creveling, C. R., and Daly, J. W. (1970). Proceedings of the National Academy of Sciences of the United States of America, 65, 1033.

Varley, H. (1969). In Practical Clinical Biochemistry, 4th edn., p. 197. London, Heinemann.

Wilson, W. S. (1969). British fournal of Pharmacology and Chemotherapy, 36, 448.
St. Bartholomew's Hospital and St. Leonard's Hospital, London

J. E. L. SALES, M.B., F.R.C.S., Senior Surgical Registrar

MARION SUTCLIFFE, A.I.M.L.T., Research Assistant

F. O'GRADY, M.D., F.R.C.PATH., Professor of Bacteriolog rapid and virtually complete (Perkins et al., 1968). Rat liver homogenates rapidly decompose some cephalosporin analogues to less active metabolites, but cephalexin is not affected and is excreted unchanged in the bile of rats. The object of the present study was to determine the concentration of cephalexin in the bile of patients undergoing surgery for biliary tract disease, to ascertain what factors affect these levels, and to assess its potential therapeutic value.

\section{Patients}

Group 1.-Nine patients with T-tubes in the common bile duct who had recovered from cholecystectomy and exploration of the common bile duct and were receiving a normal diet were given $1 \mathrm{~g}$ of cephalexin on an empty stomach or after a little light breakfast. Serum and bile samples were collected at hourly intervals for six hours. Two days later five of the patients were given $1 \mathrm{~g}$ of cephalexin together with $0.5 \mathrm{~g}$ of probenecid and samples were again collected over six hours. All these patients had normal liver function tests.

Group 2.-Thirteen patients undergoing cholecystectomy were given $500 \mathrm{mg}$ of cephalexin at six-hourly intervals over the 24 hours before operation and $500 \mathrm{mg}$ with the premedication (total dose $2.5 \mathrm{~g}$ ). At operation bile was obtained from the gall bladder by needle aspiration and when possible from the common bile duct through a fine polyethylene catheter inserted 